\section{Development and Evaluation of a Large-volume Rotary Root Separator}

\author{
Dilma Silva ${ }^{1}$, Donald Cox, and Richard C. Beeson, Jr. \\ University of Florida, Institute of Food and Agricultural Sciences, Mid-Florida \\ Research and Education Center, 2725 S. Binion Road, Apopka, FL 32703
}

Additional index words. root cleaning, root and soil separation, root dry mass quantification, root growth

\begin{abstract}
Isolation of plant roots from soil or substrate for biomass measurement is timeconsuming and can be a limiting factor influencing experimental designs, especially with mature woody plants. An electric-powered root separator was developed that sped sample preparation for root dry mass determination with a capacity of $40 \mathrm{~L}$ of container substrate or $32 \mathrm{~kg}$ of sandy soil. No water was required for machine operation and an estimated fourfold reduction in total processing time was achieved. Extent of root recovery was quantified by processing five woody plant species grown in two different container substrates and in soil, resulting in a minimum yield of $98 \%$.
\end{abstract}

Quantitative studies of plant roots are a consistent challenge. Extraction of roots from soil and debris of large samples for biomass quantification is time-consuming and tedious (Calfee, 2003). This tends to limit research to small experiments and small sample sizes, especially for woody plants with extensive root systems. Analysis of entire root systems from woody plants is particularly important, because they can allocate up to $69 \%$ of their resources to root development (Vogt et al., 1995). Still, most knowledge of woody plants roots is based on partial root extraction from soil cores and subsequent estimation of the entire root system. Roots from a single plant can be distributed differently in the surrounding soil, growing more in wet pockets of soil or with higher levels of fertility (Michelakis et al., 1993; Stevens and Douglas, 1994; Wilkin et al., 2006). Large sample sizes or samples of entire root systems would represent a more accurate account of a plant's root system.

The most common method used for root isolation has been handpicking and washing with jets of water over a sieve (Metcalfe et al., 2007). Machines for isolating roots with an elutriation system have also been reported (Benjamin and Nielsen, 2004; Brown and Thilenius, 1976; Carlson and Donald, 1986; Fribourg, 1953; Smucker et al., 1982). Unfortunately, these approaches were designed for small sample sizes, especially core soil samples. They also required large volumes of water. A drawback of elutriation systems is that final separation of roots from debris is made more difficult by adhesion of particles to themselves and roots. Additionally, changes in color make root identification and separation more difficult during final hand separation. Benjamin and Nielsen (2004) reported that up to $20 \mathrm{~h}$ was necessary to clean roots

Received for publication 4 Oct. 2010. Accepted for publication 25 Jan. 2011.

${ }^{1}$ To whom reprint requests should be addressed; e-maildilma@ufl.edu. from samples of $993 \mathrm{~cm}^{3}$ soil after machine washing.

The objective of the project reported here was to develop a fast, mechanical system to separate roots from large sample volumes with maximal root recovery, minimal root damage, and little to no water use.

\section{Material and Methods}

A root separator was developed to speed root isolation for dry mass determination (Fig. 1). Mechanical separation is provided by a rotating cylinder that removes small particles. The root separator consists of an internal basket and an external cylinder with four $38 \times 20$-cm openings at the lower end. The internal basket was $45 \mathrm{~cm}$ in diameter and $50 \mathrm{~cm}$ long. It was constructed from $6 \times$ 6-mm mesh metal hardware cloth and sewn together using twines and a bicycle tire inner

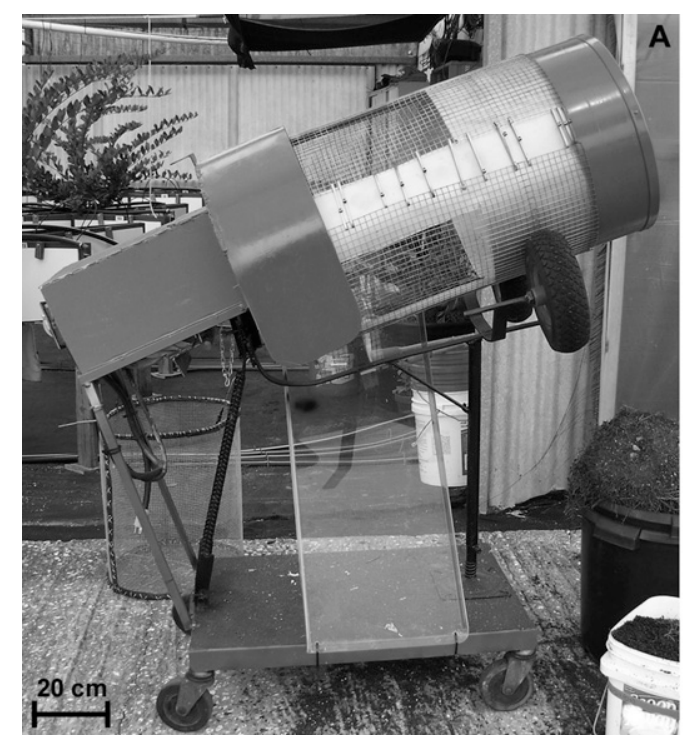
(C) Detail showing reducing transmission and motor. tube to cover the sharp edges. The outer cylinder was made from an aluminum trash can ( $79 \mathrm{~cm}$ tall and $46 \mathrm{~cm}$ in diameter) attached to a right angle gear reducer (1:20, Model 13175-20-R; Worldwide Electric, Rochester, $\mathrm{NY}$ ). A $15 \times 15-\mathrm{mm}$ wire mesh was placed on the outside of the cylinder to support the internal removal basket. The gear reducer was belt-driven by a small electric motor (Model SKH 47KR383 GS, 110 VAC, 0.75 hp, 1720 rpm; General Electric, Milwaukee, WI; Fig. 1C). The motor was shielded by a customized sheet metal box $(46 \times 30 \times 20$ $\mathrm{cm})$. The upper end of the cylinder was supported by two inflatable rubber tires $(25.4 \mathrm{~cm}$ tall $\times 7.6 \mathrm{~cm}$ wide; World Caster \& Equipment Manufacturing, Inc., Lilburn, GA) and hub assemblies attached to the heavy mobile metallic base for stability. The cylinder was set at a $20^{\circ}$ angle from the base. Samples, up to $40 \mathrm{~L}$, were placed into the internal basket. Cylinder rotation speed was adjustable. After preliminary trials, the rotational speed was established at $20 \mathrm{rpm}$ to minimize root damage. During machine use, particles smaller than wire mesh openings dropped through both the basket and the openings at the bottom of the cylinder and then were channeled aside by a polyacrylamide chute $(100 \times 40 \mathrm{~cm} \times 4 \mathrm{~mm}$ thick). After rotation, the basket was removed from the cylinder, and the remaining material was transferred to a horizontal sieve $(3 \times 3 \mathrm{~mm})$ where roots were hand-separated without water from remaining large pieces of substrate and debris. Roots were rinsed only after isolation, thus significantly reducing the use of water.

This root separator was used to isolate roots of individual Ligustrum japonicum Thum. grown in aboveground rhizotrons (Silva, 2010), which contained $0.16 \mathrm{~m}^{3}$ of substrate (Mix \#4; Conrad Fafard Inc., Agawam, MA). Twenty-four plants were grown between March and June of 2008. Rhizotron substrate was separated into four portions $(\approx 40 \mathrm{~L}$

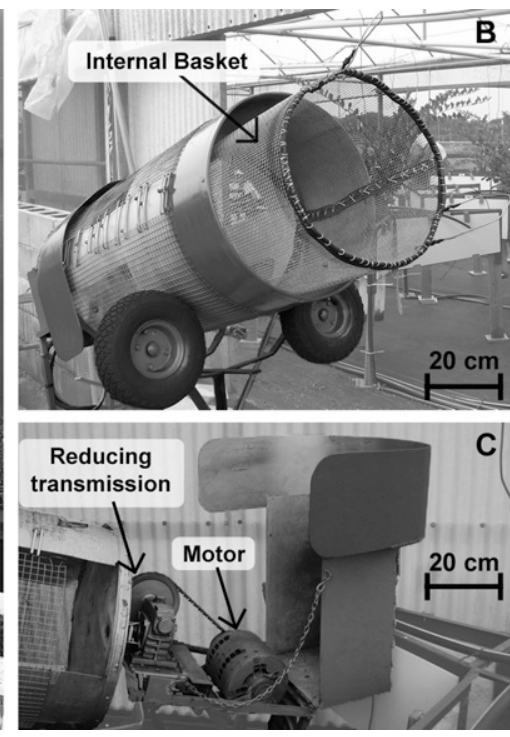

Fig. 1. Photographs of (A) root separator without the internal basket. (B) Detail showing internal basket. 
each) and then rotated for 5 to 10 min each, depending on substrate moisture level. After rinsing with water, roots were oven-dried at $65^{\circ} \mathrm{C}$ until constant dry mass was obtained.

To evaluate the general efficiency and to calculate the percentage of recovery (yield) from the root separator, root samples from five woody plant species were isolated using the machine. Entire root balls of containergrown plants of Viburnum odoratissimum Ker Gawl. (viburnum), L. japonicum (ligustrum), Illicium parviflorum Michx. (anise), and Magnolia grandiflora L. 'Little Gem' (magnolia; Table 1) were sampled for root isolation. Additionally, plants of Ilex cornuta Lindl. \& Paxt. transplanted 18 months earlier into sandy soil (Tavares-Millhopper fine sand) were also sampled. Of these plants, one-fourth of the roots that extended beyond the original root ball were used for root isolation. Rotation time was varied based on root ball size and substrate moisture level. Rotation was stopped when roots were visibly free of most small particles and remaining roots were cleaned as described previously for L. japonicum grown in rhizotrons. Root diameter was measured with a digital caliper (Model CD-6" CS; Mitutoyo America Corporation, Aurora, IL). To determine total root mass, substrate that fell from the cylinder was placed on the sieve and any additional root pieces were collected by hand. Yield was calculated as percentage of root dry mass recovered from the basket compared with the total dry root mass. Root yield from the five plant species was compared using a completely randomized design with three replications. Percent yield data were arcsin square root-transformed for data analysis (Palta, 2003). Data analysis was accomplished using SAS (Version 9.1; SAS Institute, Cary, NC).

\section{Results and Discussion}

Mechanical isolation of roots, followed by handpicking of each rhizotron's substrate $(160 \mathrm{~L})$, was completed in averaged 4 manhours (Table 2). This is four times faster than the fastest published time used for handpicking roots (Carlson and Donald, 1986) in other studies (Table 2). Using the root separator to remove small particles before handpicking led to faster cleaning; $0.025 \mathrm{~h}$ was used to clean each liter of substrate. Time required to handpick roots varies with soil type, presence of organic debris, plant species, and amount of roots in the sample. For example, Böhm et al., (1977; Table 2) reported that $4 \mathrm{~h}$ were necessary to clean roots of soybeans from 14.1-L samples. However, the soil core was $1.80 \mathrm{~m}$ deep, segmented in $0.15 \mathrm{~m}$, with $93 \%$ of roots concentrated in the top $0.45 \mathrm{~m}$ of the sample. In contrast, the web of roots produced by woody species over many years requires much longer times to clean and separate live roots from organic debris. Up to $60.3 \mathrm{~h}$ per liter of sample was required for samples originated from forested sites (Bernier et al., 2005). Metcalfe et al. (2007) reported faster root cleaning by handpicking of samples from forested sites, ranging from 0.36 to $4.11 \mathrm{~h}$ per

Table 1. Root ball volume, plant age, and substrate/soil type for each species used to evaluate the yield of the rotary root separator.

\begin{tabular}{lccl}
\hline Scientific name & $\begin{array}{c}\text { Plant age } \\
(\mathrm{yrs})\end{array}$ & $\begin{array}{c}\text { Root ball } \\
\text { volume }(\mathrm{L})\end{array}$ & \begin{tabular}{c} 
Substrate or soil type \\
\hline Viburnum odoratissimum
\end{tabular} \\
$\begin{array}{l}\text { Ligustrum japonicum } \\
\text { Ilex cornuta 'Burfordii' }\end{array}$ & 3.0 & 11.4 & Commercial substrate $^{\mathrm{z}}$ \\
Illicium parviflorum & 1.5 & 11.4 & Commercial substrate $^{\mathrm{y}}$ \\
Magnolia grandiflora 'Little Gem' & 1.0 & 40.0 & Soil $^{\mathrm{x}}$ \\
\hline
\end{tabular}

${ }^{2}$ Pine bark fine, Florida sedge peat, sand (Florida Potting Soil, Inc., Apopka, FL).

${ }^{\mathrm{y}}$ Canadian sphagnum peatmoss, processed pine bark, perlite, vermiculite, starter nutrients, wetting agents, and dolomitic limestone (Mix 4; Conrad Fafard Inc., Agawam, MA).

${ }^{x}$ Tavares-Millhopper fine sand.

Table 2. Literature review of time required to clean roots by handpicking and by machine separation preceding handpicking.

\begin{tabular}{|c|c|c|c|c|c|}
\hline Reference & Soil type & $\begin{array}{l}\text { Sample } \\
\text { volume } \\
\text { (L) }\end{array}$ & $\begin{array}{l}\text { Time used } \\
\text { to clean } \\
\text { roots (h) }\end{array}$ & $\begin{array}{c}\text { Hours to } \\
\text { clean } 1 \\
\text { L of soil }\end{array}$ & Species \\
\hline \multicolumn{6}{|l|}{ Handpicked (herbaceous) } \\
\hline $\begin{array}{l}\text { Benjamin and } \\
\text { Nielsen (2004) }\end{array}$ & Weld loam & 0.994 & Up to 20 & 20.12 & Pisum sativum $\mathrm{L}$. \\
\hline Böhm et al. (1977) & Silt loam & 14.142 & 4.0 & 0.28 & Glycine $\max$ \\
\hline $\begin{array}{l}\text { Carlson and } \\
\text { Donald (1986) }\end{array}$ & Clay & 3.200 & 0.35 & 0.11 & Cirsium arvense \\
\hline Fribourg (1953) & Not cited & 4.129 & 0.75 & 0.18 & Trifolium spp. \\
\hline \multicolumn{6}{|l|}{ Handpicked (woody) } \\
\hline Bernier et al. (2005) & Organic & 0.398 & Up to 24 & 60.30 & Forested site \\
\hline Metcalfe et al. (2007) & $\begin{array}{l}\text { Sandy Oxisol } \\
\text { and clay Oxisol }\end{array}$ & 4.620 & $1.67-19.97$ & $0.36-4.11$ & Forested site \\
\hline \multicolumn{6}{|l|}{ Machine-separated (woody) } \\
\hline This study & $\begin{array}{l}\text { Commercial } \\
\text { substrate }\end{array}$ & 160.000 & 4.0 & 0.025 & L. japonicum \\
\hline
\end{tabular}

Table 3. Dry mass of root samples and yield achieved using the rotary root separator. ${ }^{\mathrm{z}}$

\begin{tabular}{|c|c|c|c|c|}
\hline Common name & $\begin{array}{l}\text { Rotation time } \\
(\min )^{y}\end{array}$ & $\begin{array}{c}\text { Time hand } \\
\text { picking }(\mathrm{min})^{\mathrm{x}}\end{array}$ & $\begin{array}{l}\text { Dry mass } \\
\text { roots }(\mathrm{g})\end{array}$ & Yield (\%) \\
\hline$\overline{\text { Viburnum odoratissimum }}$ & 2 & 45 & 281.0 & $98.5 \mathrm{c}^{\mathrm{w}}$ \\
\hline Ligustrum japonicum & 2 & 60 & 194.0 & $99.6 \mathrm{~b}$ \\
\hline Ilex cornuta 'Burfordii' & 1 & 15 & 23.9 & $99.9 \mathrm{ab}$ \\
\hline Illicium parviflorum & 0.25 & 5 & 5.8 & $99.9 \mathrm{ab}$ \\
\hline Magnolia grandiflora 'Little Gem' & 0.25 & 5 & 6.5 & $99.9 \mathrm{a}$ \\
\hline
\end{tabular}

${ }^{z}$ Total dry mass included root mass recovered from the internal removal basket plus that recovered from the substrate shed during the rotary separation process. Yield separations were based on arcsin square roottransformed data before statistical analysis.

${ }^{\mathrm{y}}$ Rotation time for each root ball.

${ }^{\mathrm{x}}$ Average time required to separate roots from debris remaining in the internal removal basket on the 3-mm sieve before washing with water.

${ }^{\text {w}}$ Means of three repetitions. Means within column not followed by the same letter are significant at $P \leq$ 0.05 (Fisher's least significant difference).

liter to clean roots from sandy and clay soils, respectively. Rotation time ranged from $8 \%$ to $17 \%$ of total processing time.

Samples processed for yield determination included plants produced in soil and substrates with different particle sizes and components. Root samples from native sandy soil were easily cleaned using the separator. The sandy soil had a much finer texture than the Ligustrum substrate. In contrast, container root balls of magnolia, anise, and viburnum were principally composed of composted pine bark (less than $25 \mathrm{~mm}$ ). Root yield of all species was high (Table 3 ) with viburnum representing the lowest yield at $98.5 \%$ of total root dry mass. Best yield was obtained with magnolia at $99.9 \%$. The root isolation process worked best when the substrate or soil had low water content. Time required for isolation depended on soil particle size, moisture level, root density, and morphology. Drier samples need less run time because the particles do not adhere to roots as much as on wetter samples.

Plants selected had different root morphology (fine versus coarse roots) and root ball sizes, ranging from 1.5 to $160 \mathrm{~L}$. Viburnum roots were coarse (average diameter $1.43 \mathrm{~mm}$ ) and exhibited the least amount of breakage from the bulk of a root ball, whereas $L$. japonicum roots were smaller in diameter $(0.75 \mathrm{~mm})$ than viburnum roots but larger than magnolia, anise, or holly roots $(0.73,0.56$, and $0.31 \mathrm{~mm}$, respectively). Although roots of anise were the most susceptible to breakage, yield of anise roots was very high (Table 3 ). 
To minimize root breakage, especially fine lateral roots, attention was directed to minimize duration of rotation to no longer than necessary. Root recovery was good for all species tested. All substrate sieved through the internal basket was first handpicked off 3-mm sieves in full daylight and then washed to calculate the yield recovery. Most roots recovered this way were found before washing the substrate through the sieve with water. Recoveries from sieved substrate (organic or inorganic) were less than $1.5 \%$ of total dry mass despite initial substrate volumes up to 40 L. Results from plants grown in soilless substrates and the sandy soil suggested that total root cleaning time may be diminished compared with traditional handpicking. With a portable generator and larger wheels on the rotary separator, or perhaps a trailer-mounted version, the majority of soil removal for root isolations could be accomplished on-site in the field.

\section{Literature Cited}

Benjamin, J.G. and D.C. Nielsen. 2004. A method to separate plant roots from soil and analyze root surface area. Plant Soil 267:225234.

Bernier, P.Y., G. Robitaille, and D. Rioux. 2005. Estimating the mass density of fine roots of trees for minirhizotron-based estimates of productivity. Can. J. For. Res. 35:1708-1713.

Böhm, W., H. Maduakor, and H.M. Taylor. 1977. Comparison of five methods for characterizing soybean rooting density and development. Agron. J. 69:415-419.

Brown, G.R. and J.F. Thilenius. 1976. A low cost machine for separation of roots from soil material. J. Range Manage. 29:506-507.

Calfee, L.R. 2003. Post-transplant root production, mortality, and periodicity of landscape-sized shade trees. Diss., Virginia Polytechnic Institute and State University, Blacksburg, VA.

Carlson, S.J. and W.W. Donald. 1986. A washer for removing thickened roots from soil. Weed Sci. 34:794-799.

Fribourg, H.A. 1953. A rapid method for washing roots. Agron. J. 45:334-335.

Metcalfe, D.B., M. Williams, L. Aragao, A.C.L. da Costa, S.S. de Almeida, A.P. Braga, P.H.L. Goncalves, and J.D. Silva. 2007. A method for extracting plant roots from soil which facilitates rapid sample processing without compromising measurement accuracy. New Phytol. 174:697-703.
Michelakis, N., E. Vougioucalou, and G. Clapaki. 1993. Water use, wetted soil volume, root distribution and yield of avocado under drip irrigation. Agr. Water Mgt. 24:119-131.

Palta, M. 2003. Modeling binomial and binary outcomes. John Wiley \& Sons, Inc., Hoboken, NJ.

Silva, D.D. 2010. Influence of water stress, nonstructural carbohydrates and free amino acids on control of root and shoot growth of Ligustrum japonicum Thunb. Diss., University of Florida, Gainesville, FL.

Smucker, A.J.M., S.L. McBurney, and A.K. Srivastava. 1982. Quantitative separation of roots from compacted soil profiles by the hydropneumatic elutriation system. Agron. J. 74:500-503.

Stevens, R.M. and T. Douglas. 1994. Distribution of grapevine roots and salt under drip and fullground cover microjet irrigation systems. Irrig. Sci. 15:147-152.

Vogt, K.A., D.J. Vogt, P.A. Palmiotto, P. Boon, J. O'Hara, and H. Asbjornsen. 1995. Review of root dynamics in forest ecosystems grouped by climate, climatic forest type and species. Plant Soil 187:159-219.

Wilkin, M.F., N.A. Wright, D.J. Eakes, and B.C. Ebel. 2006. The effect of drought on root growth of native shrub species; Atlanta, GA; Oct. 2006 Proc. of the Southern Nursery Association Research Conference 51. 